\title{
The Use of Digital Portfolios to Enhance English as a Foreign Language Speaking Skills in Higher Education
}

\author{
https://doi.org/10.3991/ijet.v15i24.15103 \\ Paola Cabrera-Solano \\ Universidad Técnica Particular de Loja,Loja, Ecuador \\ pacabrera@utpl.edu.ec
}

\begin{abstract}
The purpose of this study is to analyze the use of digital portfolios to enhance EFL (English as a Foreign Language) speaking skills in Englishmajor undergraduate students at Universidad Tecnica Particular de Loja, in southern Ecuador. The participants were 42 students at the A2 level, according to the CEFR (Common European Framework of Reference for Languages). All of them were enrolled in an English Language Integrated Skills course. A mixed-method approach was used to collect and analyze data in this study. Pre and post-questionnaires, observation sheets, and speaking rubrics were applied as instruments. Students used their smartphones to create digital portfolios in a free storage service (Google Drive), which included videos and audios about certain topics considered in the course syllabus. The speaking activities consisted of recording information in different locations of the university campus (cafeteria, laboratories, library, chapel, sports ground), and other places of the city. The students worked individually, in pairs or groups to carry out different speaking activities during an academic term of 5 months. Personalized feedback was provided by analyzing the students' oral performance through the speech artifacts uploaded in each portfolio. The findings show that digital portfolios were effective to enhance students' pronunciation and fluency. It was also confirmed that the implementation of digital portfolios through free storage services can increase students' motivation to practice oral skills in the target language.
\end{abstract}

Keywords-Digital portfolios, EFL speaking, free storage services, higher education, smartphones

\section{Introduction}

In the field of EFL teaching and learning, speaking has been considered as the most essential among the four language skills since it determines learners' ability to use the target language efficiently [1] and [2]; certainly, as [3] states, speaking involves the active use of language to express meaning. Nevertheless, this skill has been regarded as the most challenging to master for the majority of learners [4]. In this context, the use of technology, which is nowadays an inevitable part of our life, provides the as- 
sisting tools that EFL teachers and students need for enhancing speaking [5]. One of these tools is the digital portfolio, which offers several benefits including effectiveness for the improvement of learners' speaking, autonomy, and media literacy skills [6].

Among the different technological tools that can be used to design digital portfolios in EFL education (Google Drive, Voice Thread, Evernote, Weebly, etc.), Google Drive is one of the most powerful ones. This web-based application allows learners to share files and handle them in their courses. Besides, it supports different types of file formats including documents, photos, spreadsheets, presentations, forms, among others, which can be easily used for educational purposes [7]. In fact, according to [8], the main advantage of this tool is that it offers a free online place to develop and maintain electronic portfolios through computers or smartphones. In the case of, smartphones, they can expand language learning opportunities beyond the EFL classroom [9]. Indeed, implementing mobile-based learning in EFL teaching and learning can enhance instructors' creativity in materials design, and it can increase students' motivation to learn language skills [10].

With the recent advances of technology, several studies about the use of portfolios have been conducted especially in North America and Europe [11], [12], [13], [14]; however, existing research has been mainly focused on promoting different English skills without making enough emphasis in analysing students' perceptions about their oral production. Based on the aforementioned aspects, this study attempts to address the effectiveness of digital portfolios to enhance EFL speaking so that educators motivate themselves to help students improve this skill, which is one of the most difficult language abilities for Ecuadorian students to master. It is important to remark that the use of free cloud storage tools and smartphones offers pedagogic possibilities that favor the implementation of digital speaking portfolios in higher education. In fact, despite the previously mentioned benefits, research conducted on the use of this tool to enhance EFL speaking in the Ecuadorian context has been scare. Therefore, the present study is a pioneer attempt in this field. Thus, the following research questions have been posed:

How do students perceive the use of digital portfolios to enhance speaking skills?

What is the impact of the use of digital portfolios on EFL students' speaking?

\subsection{English as a foreign language}

English is considered a lingua franca that connects people in a global world. As [15] acknowledges, the importance of English worldwide has many economic, cultural, and social reasons. In fact, [16] asserts that "There has never been in the past a language spoken more widely in the world than English is today". [17] affirms that English is a contact language for people who do not share either a common mother tongue or a common national culture. Furthermore, English constitutes a communicative tool between its users from English native-speaker backgrounds and EFL speakers of this language in international business, politics, technology, and media discourse [18]. English is also considered as the most important vehicle in the world for 
storing and transmitting information because it is the language of international communication [19].

\subsection{Communicative competence through speaking}

Speaking in a foreign language has been regarded as the most challenging among the four skills [20]. Indeed, according to [21] it is well-known that the speaking process involves a dynamic interaction between speakers and hearers, which results in spoken discourse. Due to this complexity, speaking has been recognized as an interactive, social, and contextualized communicative event. Consequently, the central role of speaking in developing learners' communicative competence has also become evident, since this skill requires learners to be able to produce not only linguistically correct but also pragmatically appropriate utterances. In this context, [22] refer to communicative competence as "a synthesis of knowledge of how language is used in social settings to perform communicative functions, and knowledge of how utterances and communicative functions can be combined according to the principles of discourse". Certainly, as [23] acknowledges, communicative competence is the speakers' ability to decide how to use different linguistic resources considering context and form.

\subsection{EFL speaking}

Speaking is widely considered one of the most important language skills to be developed in EFL education [24]. In fact, in the global era, the speaking ability is essential to achieve effective communication in the target language, especially because it allows people to communicate in a lingua franca in diverse social and cultural contexts [25][26]. In this respect, through verbal language, speaking helps people to express ideas and thoughts [27]. However, despite its importance, [28] mentions that EFL speaking is commonly perceived as a challenge for learners since they usually need a huge effort to effectively use the language in real-time. Additionally, other factors such as negotiating meaning, managing effective conversations, and speaking spontaneously are very common issues that EFL learners should face in the language acquisition process [28]. For these reasons, speaking constitutes a significant goal when communicating in the target language [29].

\subsection{ICT tools to enhance speaking through digital portfolios}

Information and Communication Technologies (ICT) have been widely used in language classes around the world [30]. EFL teachers use ICT tools for different academic purposes, especially for learning, improving, practicing, and assessing the speaking skill [31]. Among the multiple tools that EFL teachers can use to enhance students' speaking skills, digital portfolios give different benefits in terms of enhancing learners' oral production, autonomy, among others [6]. As a matter of fact, e-portfolios allow students to design and save their artifacts and also to reflect on their achievements and goals [32]. In this respect, Google Drive has been chosen for 
conducting this study because it favours synchronous communication through a webbased application that allows users to store files and edit documents collaboratively from different types of devices [33]. It is necessary to remark that other tools such as Voice Thread and Evernote were also analysed as possible alternatives to be used in this study; however, Voice Thread did not allow multiple users to have access to the same account, while Evernote did not support real-time collaboration on notes with other users. In this regard, one way to incorporate storage tools in speaking courses is the use of e-portfolios, which usually have a positive influence on undergraduates [12]. Furthermore, mobile devices such as smartphones allow teachers and students to take advantage of interactive multimedia content for academic purposes [34].

\subsection{Previous studies}

EFL students' perceptions of the use of e-portfolios to document and assess their speaking performance were explored in a study conducted by [11]. This research work intended to bridge the gap in the emerging literature on e-portfolio instruction and assessment and bring to light an alternative tool for EFL teachers to assess students' oral skills. The participants included fifty-one sophomores from two English conversation classes at a Taiwanese university. The instruments included e-portfolios, an attitude questionnaire, and interviews. The results evidenced that EFL students generally positively perceived the implementation of e-portfolios because they are useful to identify their weaker areas in speaking, offer additional oral practice opportunities, and relieve speaking anxiety. Also, learners encouraged the use of e-portfolios as a supplementary oral assessment tool that considers not only the evaluation final product but also the efforts invested during the learning process.

In a study carried out by [12], the effectiveness of using e-portfolios to develop EFL learners' speaking skills was investigated. The participants were 17 Turkish learners who were asked to record their assignments using videos and audios through an e-portfolio platform called www.lore.com. The research method used involved data collection, interviews, self-assessment papers, and cover letters. The data were analysed using content analysis. The findings revealed that e-portfolio is equally effective to develop students' speaking skills as it is with their writing skills.

In [13]'s study, the teachers' perceptions of the use of e-portfolios in speaking classes were identified. The study followed a qualitative method in which semistructured interviews were implemented and analysed through the content analysis method in terms of benefits of e-portfolios, drawbacks for learners, students' requirements, teachers' requirements, and the impact of e-portfolios on teachers. The method used was based on familiarization, coding/labelling, clustering, defining codes operationally, retrieving and organizing data, and looking for interrelationships between categories. The findings reveal that e-portfolios are helpful to measure students' progress, strengths and weaknesses, so that feedback is given positively. Also, the effective use of e-portfolios helps students to make connections about the learning process in the classroom and the use of the target language in real-life situations and contexts. 
Finally, [14] explored the network and collaborative traits that videoblogs portfolios could bring in learning English as a second language in higher education. The study was based on Vygotsky's socio-constructivist theory and Siemens' theory of connectivism. These theories were implemented in a project-based on instruction, which emphasized student-centred learning. The participants were 19 students (5 males and 14 females) aged 18-20 years old. The researches integrated technology to help students enhance their English-speaking fluency for10 weeks. Data was collected through a qualitative design using field observations, a qualitative document, and a focus group interview. After analysing the data, the main scaffolding techniques used by the participants were identified. The results revealed that learners made use of scaffolding techniques to enhance learning amongst peers throughout the vlog portfolio project.

\section{Materials and Methods}

\subsection{Setting and participants}

This study was conducted at Universidad Tecnica Particular de Loja, a private university located in southern Ecuador. The participants were 42 students (male and female, aged 19 - 25 years old) from the A2 level, according to the CEFR, who were registered in an English Language Integrated Skills course. The main purpose of this course was to develop students' listening, speaking, reading, and writing skills through a communicative integrated approach in which the exposure to authentic use of the language was permanently promoted. However, this study was particularly focused on enhancing students' speaking performance.

\subsection{Instruments and materials}

- A pre-questionnaire was used to diagnose the students' background knowledge regarding the use of digital portfolios for EFL learning as well as to identify if they perceived themselves as skilful in using storage tools through smartphones. This instrument was based on a 5-point Likert scale that included 10 questions and was administered through the Survey Monkey tool (see Appendix 1)

- Observation checklists were also used to obtain further information about aspects related to EFL speaking, motivation, use of the storage tool, use of smartphones, and feedback (see Appendix 2)

- Speaking rubrics adapted from Cambridge English Qualifications [35] were applied to assess the quality of the speaking artifacts saved by students in their portfolios through the storage tool (in terms of pronunciation, grammar, vocabulary, fluency, and originality) (see Appendix 3)

- A post-questionnaire was also administered to identify the participants' perceptions after using digital portfolios as a resource for enhancing EFL speaking skills. It consisted of 10 questions with similar characteristics to the ones included in the 
pre-questionnaire, and it was useful to obtain quantitative and qualitative data about instruction intervention (see Appendix 4)

\subsection{Procedure}

The data for this study were gathered for five months in the academic period of October 2019-February 2020. A mixed-method approach, which included both quantitative and qualitative data analyses was used in this research. According to [36], the core assumption of this approach is that the use of both qualitative and quantitative methods allows a more complete comprehension of a research problem than either method alone.

Concerning the step-by-step procedure (see Fig.1), after the pre-questionnaires were applied, and those results were analysed, students were part of an intervention that consisted of using their smartphones to create digital speaking portfolios and organize them in the storage tool chosen for this study (Google Drive). The participants were asked to work either individually, in pairs, or groups to carry out different speaking activities dealing with describing interesting places and people, giving opinions about different situations, talking about their family and friends, and pronouncing lists of words. Besides, the portfolios included artifacts such as videos and audios recorded in different locations of the university campus (cafeteria, laboratories, library, chapel, sports ground), and other places of the city (see Fig 2). During this process, personalized written and oral feedback was provided based on the students' speaking performance which was evidenced through the artifacts included in each portfolio. To do this, the rubrics adapted from [35] were used to assess the quality of each speaking artifact considering linguistic aspects such as pronunciation, grammar, vocabulary, and fluency at an A2 level. It is necessary to mention that originality was another element considered for assessing students' academic performance because the process of recording videos and audios was also intended to promote the participants' creativity.

Additionally, during the aforementioned intervention, 8 lessons were systematically observed to register learners' attitudes regarding portfolio construction. At the end of this process, the post-questionnaire was administered to determine the participants' perceptions regarding the impact of digital portfolios to practice EFL speaking. It is necessary to remark that the pre and post questionnaires were piloted and validated with similar groups of students before being administered. As for the analysis, descriptive statistics and frequency distributions were calculated using Excel spreadsheets; this process was useful to obtain graphical representations of data. The main findings were then triangulated with the results of the speakers' academic performance and systematic observations. 


\begin{tabular}{|c|c|}
\hline \multicolumn{2}{|c|}{ Observation checklist } \\
\hline $\begin{array}{c}\text { Pre- } \\
\text { questionnaire } \\
\downarrow\end{array}$ & $\begin{array}{c}\text { Survey } \\
\text { Monkey }\end{array}$ \\
\hline Tools & Smartphone \\
\hline$\downarrow$ & $\begin{array}{c}\text { Videos / } \\
\text { Audios }\end{array}$ \\
\hline $\begin{array}{c}\text { Artifacts } \\
\text { design }\end{array}$ & $\begin{array}{c}\text { Google Drive } \\
\text { Portfolio }\end{array}$ \\
\hline \multicolumn{2}{|c|}{$\downarrow$}
\end{tabular}
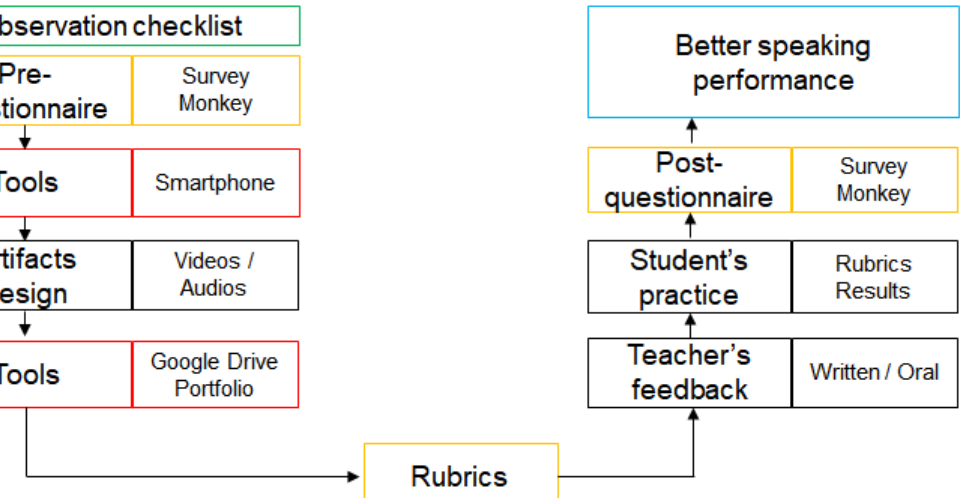

Fig. 1. Methodological procedure

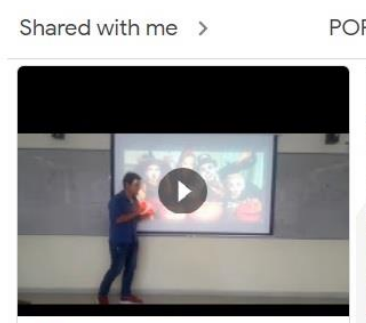

PORTFOLIO > Speaking portfolio * _

w.w WhatsApp Video 2019-10-29 at ...

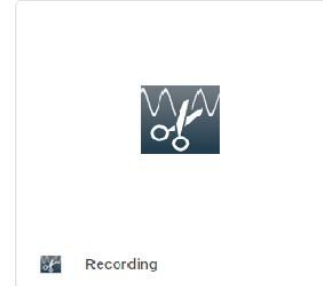

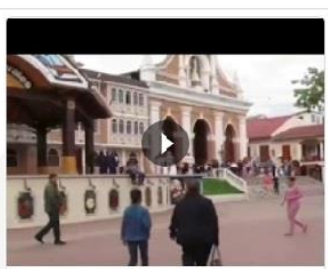

แ

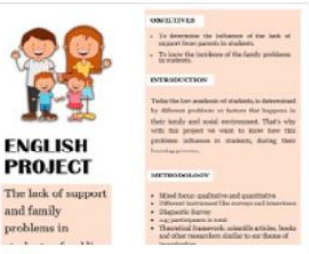

•IMG-20180719-WA0040.jpg

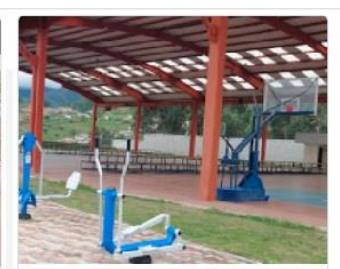

• IMG_20190416_084538.jpg

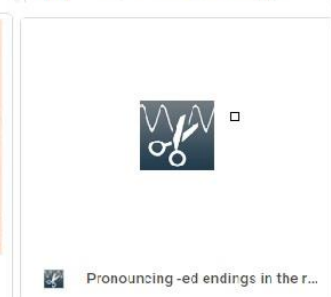

Fig. 2. Sample of students' digital portfolios

\section{Results and Discussion}

Before the intervention, some background information about students' previous knowledge of the use of digital portfolios for enhancing EFL speaking was obtained. In addition, the participants' technological skills in using storage tools through smartphones were identified. Generally speaking, most of the students had a neutral position about the use of digital portfolios as a tool that could help them to improve their oral skills (see Figure 3). Regarding learners' perceptions about their technological skills for using storage tools in their smartphones, $67.33 \%$ of them affirmed that 
they knew how to use them for academic purposes. Concerning the students' experience of using digital portfolios, $48.47 \%$ of them asserted that they had used them before, especially in writing courses of their major. Based on the opinions above, it was found out that the students practically did not have previous experience in using EFL speaking portfolios.

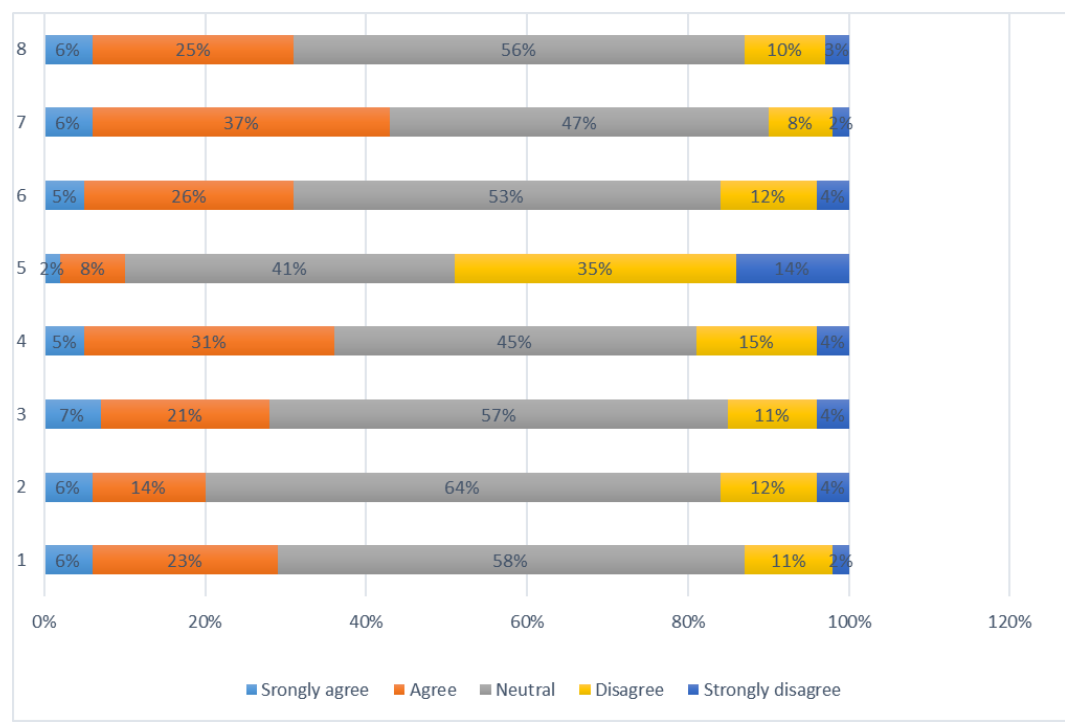

Fig. 3. Students' previous perceptions about digital speaking portfolios

After conducting the intervention, students' perceptions of the use of digital portfolios were statistically analysed in aspects concerning their impression about motivation, organization facilities, feedback, effectiveness of audio and video recordings, and improvement of linguistic skills. The results are shown in Table 1.

Table 1. Students' perceptions regarding the use of digital portfolios

\begin{tabular}{|c|l|c|c|c|c|c|}
\hline No. & \multicolumn{1}{|c|}{ Statements } & $\begin{array}{c}\text { Strongly } \\
\text { agree } \\
(\%)\end{array}$ & $\begin{array}{c}\text { Agree } \\
(\%)\end{array}$ & $\begin{array}{c}\text { Neutral } \\
(\%)\end{array}$ & $\begin{array}{c}\text { Disagree } \\
(\%)\end{array}$ & $\begin{array}{c}\text { Strongly } \\
\text { disagree } \\
(\%)\end{array}$ \\
\hline 1 & The use of digital portfolios was motivating. & 63.45 & 31.11 & 3.44 & 2.00 & 0 \\
\hline 2 & $\begin{array}{l}\text { The storage tool allowed me to organize my } \\
\text { digital speaking portfolio. }\end{array}$ & 68.78 & 25.16 & 4.62 & 1.44 & 0 \\
\hline 3 & $\begin{array}{l}\text { The organization of the digital portfolio } \\
\text { facilitated the practice of speaking. }\end{array}$ & 81.45 & 13.74 & 2.95 & 1.86 & 0 \\
\hline 4 & $\begin{array}{l}\text { The digital portfolio facilitated the feedback } \\
\text { process. }\end{array}$ & 92.66 & 4.45 & 1.46 & 1.43 & 0 \\
\hline 5 & $\begin{array}{l}\text { The use of smartphones was effective to } \\
\text { record videos and audios. }\end{array}$ & 68.30 & 26.30 & 4.20 & 1.20 & 0 \\
\hline 6 & $\begin{array}{l}\text { The use of digital portfolios allowed me to } \\
\text { improve grammar and vocabulary in oral }\end{array}$ & 68.70 & 28.20 & 2.10 & 1.10 & 0 \\
\hline
\end{tabular}


Paper-The Use of Digital Portfolios to Enhance English as a Foreign Language Speaking Skills in..

\begin{tabular}{|c|l|c|c|c|c|c|}
\hline & production. & & & & & \\
\hline 7 & $\begin{array}{l}\text { The use of digital portfolios allowed me to } \\
\text { improve pronunciation and fluency in oral } \\
\text { production. }\end{array}$ & 77.10 & 19.80 & 2.30 & 0.8 & 0 \\
\hline 8 & $\begin{array}{l}\text { My digital portfolio allowed me to improve } \\
\text { my speaking. }\end{array}$ & 87.90 & 8.30 & 3.50 & 0.30 & 0 \\
\hline
\end{tabular}

Regarding the use of the storage tool to organize students' digital speaking portfolios (table 2), 68.78\% of the participants indicated that they strongly agree with this factor, and $25.16 \%$ agree. During the observations, it was evident that the use of this storage service was easy for students to manage because they could use it without any difficulty. It is necessary to mention that a very low percentage of $1.44 \%$ considered that this tool was not useful for this purpose. These findings are fairly consistent with the existing research conducted by [37] who mentioned that using a file storage service is a valuable tool that can be used to guide EFL students understanding along the learning process.

Concerning whether the organization of the digital portfolio facilitated the practice of speaking, a significant percentage of students $(81.45 \%)$ strongly agreed with this aspect, and $13.74 \%$ showed agreement. Only $2.95 \%$ of the participants had a neutral opinion about this factor. As for the observation, students seemed active and engaged during the process of audio and video recording. Certainly, the organization of their digital portfolio helped students practice by doing, and was useful to keep a record of their ability to speak in the target language. In fact, [38] affirms that the use of portfolios is beneficial not only to enhance EFL speaking but also to improve academic achievement.

As for feedback, $92.66 \%$ of the students perceived that the use of digital portfolios favoured the feedback process, while, a low percentage of learners (1.43\%) disagreed with this aspect. In line with the observations, students showed a positive attitude towards individual and group feedback to develop their English-speaking skills. Indeed, they looked very grateful when the teacher made them repeat the pronunciation of certain words, or when linguistic aspects such as grammar and vocabulary were discussed. In this respect, [13] remark that e-portfolios help instructors keep track of students' progress by identifying their weaknesses when speaking in English.

Regarding the participants' perceptions of the use of smartphones as effective tools to record videos and audios, most of them (94.6\%) strongly agreed and agreed with the statement. Nevertheless, a few students $(4.20 \%)$ were neutral while $1.20 \%$ of them disagreed. Certainly, researchers observed that students easily used their smartphones for recording their audios and videos. As [39] acknowledges, smartphones are frequently used for video production with different learning purposes in a wide range of educational contexts, this is possible because the technological development of smartphones and their video recording feature allows students to use them as portable and personal language learning tools.

Concerning the participants' perceived benefits of digital portfolios for enhancing oral production, the aspects considered were grammar, vocabulary, pronunciation, and fluency. Thus, $96.9 \%$ of the students strongly agreed and agreed that digital portfoli- 
os allowed them to improve pronunciation and fluency. However, $2.30 \%$ were neutral, and only $0.8 \%$ expressed disagreement. As for grammar and vocabulary, $68.70 \%$ of the participants strongly agreed and $28.20 \%$ agreed on the benefits of digital portfolios for enhancing their grammar and vocabulary knowledge when speaking, while a minimum percentage of $3.20 \%$ were either neutral or in disagreement with the aforementioned aspects. These results were corroborated by the observations in which it was evident that most of the students had the opportunity to improve their speaking skills through the activities that were implemented. Certainly, research reveals several benefits of the use of digital portfolios for improving speaking; thus, [12] assert that students' perceptions regarding the use of e-portfolios in speaking are positive in terms of grammar, pronunciation, vocabulary, self-confidence, and motivation.

The participants expressed their perceptions regarding the improvement of their speaking skills as a result of the use of digital portfolios. Most of them $(87.90 \%)$ strongly agreed with this statement, $8.30 \%$ agreed, and $3.80 \%$ did not express agreement or disagreement. It is important to remark that nobody disagreed with the aforementioned statement. In this regard, [40] emphasize that speaking portfolios offer learners outstanding benefits including self-reflection, peer-feedback, and general improvement of their speaking skills.

To complement the previous analysis, Table 2 presents the main aspects that were observed by the researchers during the intervention process.

Table 2. Use of digital portfolios to enhance EFL speaking

\begin{tabular}{|l|l|}
\hline \multicolumn{1}{|c|}{ Dimensions } & \multicolumn{1}{c|}{ Students' attitudes observed during the intervention } \\
\hline Speaking & Students improved their oral production \\
\hline Motivation & $\begin{array}{l}\text { Participants were engaged in the process of creating their artifacts and } \\
\text { organizing their digital portfolios. }\end{array}$ \\
\hline Use of file storage service & The use of file storage services was easy for students. \\
\hline Use of Smartphones & Students used their smartphones to organize their portfolios easily. \\
\hline Feedback & $\begin{array}{l}\text { Students showed a positive attitude towards individual and group feed- } \\
\text { back. }\end{array}$ \\
\hline
\end{tabular}

Finally, after assessing the final speaking portfolios through the use of rubrics adapted from [35] (Figure 2), the results demonstrated outstanding media scores in terms of pronunciation ( 8.4 points), and fluency ( 8.2 points). The assessment was conducted through a careful analysis of students' performance in the different videos and audios that they recorded during the intervention. Indeed, at the end of the course students were able to exchange information, and describe matters of immediate need in simple terms, which is a learning outcome established at the A2 CEFR proficiency level. Furthermore, the scores in the originality aspect were also noticeable even though this factor was not directly related to the speaking skill; this might be the result of students' engagement and creativity with the portfolio organization. 


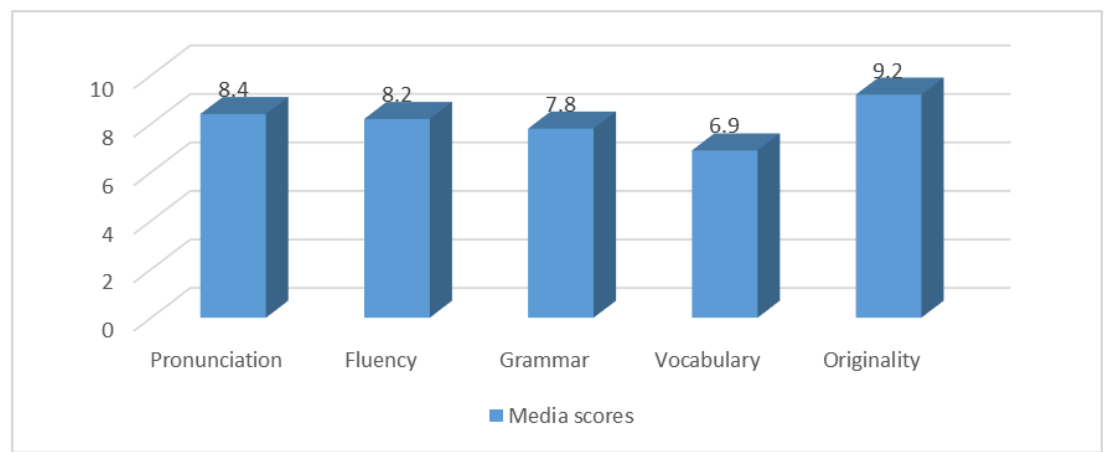

Fig. 4. Students' media scores in final digital portfolios

\section{Conclusion}

The use of digital portfolios is motivating for enhancing EFL speaking skills at the A2 CEFR level. Students were engaged in the process of recording audios and videos since they had the opportunity to visit different locations at the university campus (cafeteria, laboratories, library, chapel, sports ground), and other places of the city. Besides, they demonstrated to be proud of themselves when organizing creative and original artifacts.

Free cloud storage services and smartphones are easy-to-use ICT tools for creating and saving EFL speaking portfolios. University students and teachers can use these tools to record, store, and organize audio and video files effectively. This allows instructors to keep a record of students' artifacts, analyse them, and provide personalized feedback along the learning process.

The organization of digital portfolios helps students practice their speaking skills. This is evident since learners' practice by doing, which is a positive factor because they become more active and look for opportunities to improve their oral language skills. As students systematically record their artifacts, they feel more confident to speak the target language.

Digital portfolios allow teachers to provide timely feedback because of the facilities offered by smartphones and free storage services. Students were grateful when the teacher assessed their speaking performance because this process helped them to improve this language skill. Certainly, the most important benefits of digital portfolios in teaching EFL speaking are related to grammar, vocabulary, pronunciation, and fluency. Among all of these aspects, pronunciation and fluency are the most outstanding according to students' perceptions.

It is necessary to mention that an important limitation of this study was the reduced sample of participants. Since this research was conducted with only 42 students from one private university in Ecuador, the findings obtained may not be generalized in other contexts. Further research about the innovative use of digital speaking portfolios should be conducted to help students improve their EFL oral skills through the use of technology. 


\section{Acknowledgement}

I would like to acknowledge the Research Department at Universidad Técnica Particular de Loja for promoting and supporting research projects through the EFL Learning, Teaching and Technology Research Group.

\section{References}

[1] P. Ur, "A course in language teaching: Practice \& Theory (pp. 184-187)". Cambridge: Cambridge University Press, 1996.

[2] M. Y. Abdullah, S. Hussin, en K. Ismail, "Implementation of Flipped Classroom Model and Its Effectiveness on English Speaking Performance”, Int. J. Emerg. Technol. Learn., vol 14, no 09, bll 130-147, 2019. https://doi.org/10.3991/ijet.v14i09.10348

[3] S. Al Hosni, "Speaking difficulties encountered by young EFL learners", Int. J. Stud. English Lang. Lit., vol 2, no 6, bll 22-30, 2014.

[4] S. Zhang, "The Role of Input, Interaction and Output in the Development of Oral Fluency.”, English Lang. Teach., vol 2, no 4, bll 91-100, 2009.

[5] T. Han en F. Keskin, "Using a mobile application (WhatsApp) to reduce EFL speaking anxiety”, Gist Educ. Learn. Res. J., no 12, bll 29-50, 2016.

[6] J. Lao-un en D. Khampusaen, "Using Electronic Portfolio to Promote English Speaking Ability of EFL Undergraduate Students".

[7] A. Sadik, "Students' acceptance of file sharing systems as a tool for sharing course materials: The case of Google Drive", Educ. Inf. Technol., vol 22, no 5, bll 2455-2470, 2017. https://doi.org/10.1007/s10639-016-9556-z

[8] R. Rabbani Yekta en M. A. Kana'ni, "Using Google Drive as the E-portfolio for the Selfassessment of Speaking Fluency", Int. J. Res. English Educ., bll 30-39.

[9] J. Wrigglesworth, "Using smartphones to extend interaction beyond the EFL classroom", Comput. Assist. Lang. Learn., bll 1-22, 2019. https://doi.org/10.1080/09588221.2019.1569 $\underline{067}$

[10] E. Elfiona, M. Zaim, en others, "Mobile-Based Media as the Solution in Teaching and Learning Listening Skill”, in Journal of Physics: Conference Series, 2019, vol 1387, no 1, bl 12024. https://doi.org/10.1088/1742-6596/1387/1/012024

[11] H.-T. D. Huang en S.-T. A. Hung, "Implementing electronic speaking portfolios: Perceptions of EFL students”, Br. J. Educ. Technol., vol 41, no 5, bll E84--E88, 2010. https://doi. org/10.1111/j.1467-8535.2009.00996.x

[12] S. Cepik en A. E. Yastibas, "The use of e-portfolio to improve English speaking skill of Turkish EFL learners", Anthropol., vol 16, no 1-2, bll 307-317, 2013. https://doi.org/10. 1080/09720073.2013.11891358

[13] A. E. Yastibas en S. Cepik, "Teachers' attitudes toward the use of e-portfolios in speaking classes in English language teaching and learning”, Procedia-Social Behav. Sci., vol 176, bll 514-525, 2015. https://doi.org/10.1016/j.sbspro.2015.01.505

[14] A. Shuib, L. Ismail, en U. K. Abdul Manaf, "Scaffolding speaking tasks using videoblog portfolio in an ESL classroom", Univers. J. Educ. Res., vol 8, no 1 A, bll 44-52, 2020. https://doi.org/10.13189/ujer.2020.081307

[15] E. Lewandowska, "English as a Lingua Franca: An Overview of Communicative Strategies.”, Rethink. Dir. Lang. Learn. Teach. Univ. Lev., bl 27, 2019. 
[16] J. Melitz, "English as a global language", in The Palgrave handbook of economics and language, Springer, 2016, bll 583-615. https://doi.org/10.1007/978-1-137-32505-1 21

[17] A. Firth, "The discursive accomplishment of normality: On 'lingua franca'English and conversation analysis", J. Pragmat., vol 26, no 2, bll 237-259, 1996. https://doi.org/10.10 16/0378-2166(96)00014-8

[18] B. Seidlhofer, "Anglophone-centric attitudes and the globalization of English". De Gruyter Mouton, 2012. https://doi.org/10.1515/jelf-2012-0026

[19] C. Alptekin, "Towards intercultural communicative competence in ELT", ELT J., vol 56, no 1, bll 57-64, 2002. https://doi.org/10.1093/elt/56.1.57

[20] M. C. Murcia en E. Olshtain, "Discourse and context in language teaching". Cambridge: Cambridge University Press, 2000.

[21] E. U. Juan en A. M. Flor, Current trends in the development and teaching of the four language skills, vol 29. Walter de Gruyter, 2006.

[22] M. Canale en M. Swain, "Theoretical bases of communicative approaches to second language teaching and testing", Appl. Linguist., vol 1, no 1, bll 1-47, 1980. https://doi.org/ 10.1093/applin/I.1.1

[23] G. Kasper, "Classroom research on interlanguage pragmatics", Pragmat. Lang. Teach., bll 33-60, 2001.

[24] L. A. I. M. E. I. LEONG en S. M. Ahmadi, "An analysis of factors INFLUENCING LEARNERS'ENGLISH SPEAKING SKILL”, 2017.

[25] T. Isaacs, “Assessing speaking”, Handb. Second Lang. Assess., bll 131-146, 2016.

[26] M. A. Abugohar, K. Yunus, en R. Ab Rashid, "Smartphone applications as a teaching technique for enhancing tertiary learners' speaking skills: Perceptions and Practices", Int. J. Emerg. Technol. Learn., vol 14, no 09, bll 74-92, 2019. https://doi.org/10.3991/ ijet.v14i09.10375

[27] U. Fauzan, "The use of improvisations technique to improve the speaking ability of EFL students", Din. Ilmu, vol 14, no 2, bll 264-287, 2014. https://doi.org/10.21093/di.v14i2.17

[28] U. Fauzan, "Enhancing speaking ability of EFL students through debate and peer assessment", EFL J., vol 1, no 1, bll 49-57, 2016. https://doi.org/10.21462/eflj.v1i1.8

[29] D. Nunan, Second Language Teaching \& Learning. ERIC, 1999.

[30] F. Amiri, "IT-literacy for language teachers: should it include computer programming?", System, vol 28, no 1, bll 77-84, 2000. https://doi.org/10.1016/S0346-251X(99)00061-5

[31] S. M. Alsied en M. M. Pathan, "The use of computer technology in EFL classroom: Advantages and implications", Int. J. English Lang. Transl. Stud., vol 1, no 1, bll 44-51, 2013.

[32] G. Bisovsky en S. Schaffert, "Learning and teaching with E-Portfolios: Experiences in and challenges for adult education", Int. J. Emerg. Technol. Learn., vol 4, no 1, bll 13-15, 2009. https://doi.org/10.3991/ijet.v4i1.822

[33] L. A. Rosique-Martinez, G. Dominguez-Barrera, en J. Izquierdo, "The attitudes of Englishas-a-Foreign-Language students towards the learning usefulness and benefits of GoogleDrive for Collaborative Writing", Cinzontle, vol 8, no 17, 2018.

[34] Y.-L. Jeng, T.-T. Wu, Y.-M. Huang, Q. Tan, en S. J. H. Yang, "The add-on impact of mobile applications in learning strategies: A review study", J. Educ. Technol. Soc., vol 13, no 3, bll 3-11, 2010.

[35] UCLES, “Cambridge English Qualifications", 2008. [Online]. Available at: https://www. cambridgeenglish.org/images/168617-assessing-speaking-performance-at-level-a2.pdf.

[36] J. W. Creswell, Educational research: Planning, conducting, and evaluating quantitative. Prentice Hall Upper Saddle River, NJ, 2002. 
[37] C. Bauer-Ramazani en C. Sabieh, "4 CALL AND PROJECT-BASED LEARNING IN BLENDED AND ONLINE COURSES”, Eur. J. Appl. Linguist. TEFL, vol 7, no 2, bll 85102, 2018.

[38] F. Wicaksono, "DESIGNING PORTFOLIO ASSESSMENT OF SPEAKING SKILL FOR VOCATIONAL HIGH SCHOOL STUDENTS”, in UNNES-TEFLIN National Seminar, 2017, bll 149-162.

[39] N. A. Gromik, "The effect of theme preference on academic word list use: A case for smartphone video recording feature", Educ. Inf. Technol., vol 22, no 5, bll 2087-2101, 2017. https://doi.org/10.1007/s10639-016-9533-6

[40] M. Safari en M. Koosha, "Instructional Efficacy of Portfolio for Assessing Iranian EFL Learners' Speaking Ability.”, English Lang. Teach., vol 9, no 3, bll 102-116, 2016. https:// doi.org/10.5539/elt.v9n3p102

\section{Author}

Paola Cabrera-Solano is a Master in Distance Education and a Master in Teaching English as a Foreign Language from Universidad Técnica Particular de Loja and Nova Southeastern University of the United States. With undergraduate studies in Teaching English as a Foreign Language and Business Administration. Language and Linguistics Doctoral student at Universidad Nacional de Rosario, Argentina. Former administrative coordinator of the Master's Degree in TEFL, and Former Head of the English Language Teaching Unit. Research professor in the Contemporary Languages Section of the Department of Education, and member of the Research Group "EFL Learning, Teaching and Technology"

Article submitted 2020-04-21. Resubmitted 2020-07-31. Final acceptance 2020-08-22. Final version published as submitted by the authors. 


\section{Appendices}

\subsection{Pre-questionnaire}

Purpose: The aim of this questionnaire is to collect information to identify your prior knowledge about the use of digital portfolios as a technological tool for enhancing EFL speaking.

Instruction: Read the following statements which may or may not describe your beliefs about digital speaking portfolios. Rate each statement by circling a number between 1 and 5 where the numbers mean:

- 5. Strongly disagree

- 4. Disagree

- 3. Neutral

- 2. Agree

- 1. Strongly agree

\begin{tabular}{|c|l|c|c|c|c|c|}
\hline $\mathbf{N}^{\circ}$ & \multicolumn{1}{|c|}{ Statements } & $\mathbf{1}$ & $\mathbf{2}$ & $\mathbf{3}$ & $\mathbf{4}$ & $\mathbf{5}$ \\
\hline 1 & The use of digital portfolios is motivating. & & & & & \\
\hline 2 & Storage tools allow students to organize a digital speaking portfolio. & & & & & \\
\hline 3 & $\begin{array}{l}\text { The organization of the digital portfolio facilitates the practice of } \\
\text { speaking. }\end{array}$ & & & & \\
\hline 4 & Digital portfolios facilitate the feedback process. & & & & \\
\hline 5 & $\begin{array}{l}\text { The use of smartphones is effective to record videos and audios for } \\
\text { academic purposes, }\end{array}$ & & & & \\
\hline 6 & $\begin{array}{l}\text { The use of digital portfolios allows learners to improve grammar and } \\
\text { vocabulary in oral production. }\end{array}$ & & & & \\
\hline 7 & $\begin{array}{l}\text { The use of digital portfolios helps students to improve pronunciation } \\
\text { and fluency in oral production. }\end{array}$ & & & & & \\
\hline 8 & Digital portfolios allow students to improve my speaking. & & & & \\
\hline
\end{tabular}

9. Do you know how to use storage tools on your smartphone? If so, can you explain your technological skills for using them for academic purposes?

Yes ( )

No ( )

Explain:

10. Have you ever used digital portfolios in any of the language courses you have taken as part of your Major? If so, can you describe your previous experience?

Yes ( )

No ()

Explain: 


\subsection{Observation checklist}

\begin{tabular}{|c|c|c|c|}
\hline Questions & Yes & No & Comments \\
\hline $\begin{array}{l}\text { The students had a positive attitude in communicative activities that involved oral } \\
\text { production }\end{array}$ & & & \\
\hline $\begin{array}{l}\text { Students were motivated when organizing their artifacts through video and audio } \\
\text { recordings }\end{array}$ & & & \\
\hline The teaching strategies were effective for enhancing speaking at an A2 level & & & \\
\hline The use of the file storage service was easy for students & & & \\
\hline $\begin{array}{l}\text { Students could use their smartphones to organize their portfolios without any } \\
\text { difficulty }\end{array}$ & & & \\
\hline $\begin{array}{l}\text { The teacher provided individual feedback to reinforce students' speaking perfor- } \\
\text { mance }\end{array}$ & & & \\
\hline The teacher provided group feedback according to the students' learning needs. & & & \\
\hline
\end{tabular}

\subsection{Speaking rubrics}

\begin{tabular}{|c|c|c|c|}
\hline $\begin{array}{c}\text { CEFR } \\
\text { A2 }\end{array}$ & $\begin{array}{c}\text { Exceeds expectations } \\
6.68-10 \\
\end{array}$ & $\begin{array}{c}\text { Meets expectations } \\
3.34-6,67 \\
\end{array}$ & $\begin{array}{c}\text { Needs improvement } \\
0-\mathbf{3 , 3 3}\end{array}$ \\
\hline Fluency & $\begin{array}{l}\text { The student maintains simple } \\
\text { exchanges and needs } \\
\text { very little assistance or support. }\end{array}$ & $\begin{array}{l}\text { The student maintains simple } \\
\text { exchanges, despite some } \\
\text { difficulty; however, he/she } \\
\text { might need support from the } \\
\text { teacher. }\end{array}$ & $\begin{array}{l}\text { The student has considera- } \\
\text { ble difficulty to maintain } \\
\text { simple exchanges. Addi- } \\
\text { tional support is needed. }\end{array}$ \\
\hline Pronunciation & $\begin{array}{l}\text { Student's pronunciation is } \\
\text { mostly intelligible and has good } \\
\text { control of phonological aspects } \\
\text { at both utterance and word } \\
\text { levels. }\end{array}$ & $\begin{array}{l}\text { Student's pronunciation is } \\
\text { mostly intelligible, despite an } \\
\text { evidently limited control of } \\
\text { phonological features. }\end{array}$ & $\begin{array}{l}\text { The student has very limited } \\
\text { control of phonological } \\
\text { features and is often unin- } \\
\text { telligible when pronouncing } \\
\text { in the target language. }\end{array}$ \\
\hline Grammar & $\begin{array}{l}\text { The student has a good degree } \\
\text { of control of simple grammati- } \\
\text { cal forms at this level. }\end{array}$ & $\begin{array}{l}\text { The student shows sufficient } \\
\text { control of simple grammatical } \\
\text { forms at this level. }\end{array}$ & $\begin{array}{l}\text { The student shows only } \\
\text { limited control of a few } \\
\text { grammatical forms at this } \\
\text { level. }\end{array}$ \\
\hline Vocabulary & $\begin{array}{l}\text { The student uses a variety of } \\
\text { appropriate vocabulary when } \\
\text { talking about everyday situa- } \\
\text { tions. }\end{array}$ & $\begin{array}{l}\text { The student uses appropriate } \\
\text { vocabulary to talk about } \\
\text { everyday situations. }\end{array}$ & $\begin{array}{l}\text { The student uses a vocabu- } \\
\text { lary of isolated words and } \\
\text { phrases. }\end{array}$ \\
\hline Originality & $\begin{array}{l}\text { Originality, insight, and creativ- } \\
\text { ity are evidenced in the speak- } \\
\text { ing portfolio. }\end{array}$ & $\begin{array}{l}\text { Originality, insight, and } \\
\text { creativity are demonstrated } \\
\text { sometimes; the student tries to } \\
\text { contribute, but the final } \\
\text { portfolio does not go beyond } \\
\text { the expectations. }\end{array}$ & $\begin{array}{l}\text { Originality, insight, and } \\
\text { creativity are not clearly } \\
\text { demonstrated; the final } \\
\text { portfolio is not creative at } \\
\text { all. }\end{array}$ \\
\hline
\end{tabular}

Rubric adapted from Cambridge English Qualifications [35]

\subsection{Speaking rubrics}

Purpose: The aim of this questionnaire is to collect information concerning your perceptions about the use of digital portfolios as a technological tool for enhancing EFL speaking. 
Instruction: Read the following statements which may or may not describe your beliefs about digital speaking portfolios. Rate each statement by circling a number between 1 and 5 where the numbers mean:

- 5. Strongly disagree

- 4. Disagree

- 3. Neutral

- 2. Agree

- 1. Strongly agree

\begin{tabular}{|c|c|c|c|c|c|c|}
\hline No. & Statements & 1 & 2 & 3 & 4 & 5 \\
\hline 1 & The use of digital portfolios was motivating. & & & & & \\
\hline 2 & The storage tool allowed me to organize my digital speaking portfolio. & & & & & \\
\hline 3 & The organization of the digital portfolio facilitated the practice of speaking. & & & & & \\
\hline 4 & The digital portfolio facilitated the feedback process. & & & & & \\
\hline 5 & The use of smartphones was effective to record videos and audios. & & & & & \\
\hline 6 & $\begin{array}{l}\text { The use of digital portfolios allowed me to improve grammar and vocabu- } \\
\text { lary in oral production. }\end{array}$ & & & & & \\
\hline 7 & $\begin{array}{l}\text { The use of digital portfolios allowed me to improve pronunciation and } \\
\text { fluency in oral production. }\end{array}$ & & & & & \\
\hline 8 & My digital portfolio allowed me to improve my speaking. & & & & & \\
\hline
\end{tabular}

9. How do you describe your experience of using storage tools on your smartphone? 10. Would you like to continue using digital portfolios for enhancing EFL speaking skills?

Yes ( )

No ( ) 